\title{
Validation of spectrophotometric method to detect and quantify nitrite in ham pate
}

\author{
Patrícia Barros Reis ${ }^{1 *}$, Rodrigo Mauro Ramos², Leonardo Francisco de Souza², Silvana de \\ Vasconcelos Cançado ${ }^{3}$
}

\begin{abstract}
${ }^{1}$ Departament of Technology and Inspection of Products from Animal Origin, School of Veterinary Medicine, Federal University of Minas Gerais, ${ }^{2}$ Agriculture, Livestock and Supplying Ministry, National Agricultural Laboratory, ${ }^{3}$ Departament of Technology and Inspection of Products from Animal Origin, School of Veterinary Medicine, Federal University of Minas Gerais
\end{abstract}

\begin{abstract}
The objective of this work was to validate the spectrophotometric method to detect and quantify nitrite using ham pate as a source. The validated analytical conditions were $540 \mathrm{~nm}$ wavelength and the samples reading between 40 to 70 minutes after addition of coloring agents. The tested performance criteria were: linearity, matrix effect, selectivity, detection and quantification limit, accuracy, precision and robustness. As the results have obtained linearity in the studied zone $(0.125$ to $3 \mathrm{~g} / \mathrm{mL})$ and matrix effect was not observed, there was not any interference from ascorbic acid, but interference occurred from sodium eritorbate, in concentrations above $2.5 \mathrm{mg} / 100 \mathrm{~g}$. The detection limit was defined as 12.5 $\mathrm{mg}$ of nitrite $/ \mathrm{kg}$ for pate and the quantification limit as $25 \mathrm{mg}$ of nitrite $/ \mathrm{kg}$ of pate. The method presented repeatability and reproducibility. The accuracy was assessed through recovery values varying from 84 to $110 \%$. Respecting robustness, it was observed that the variations applied to the extraction procedure depended on the concentration of nitrite in the pate sample. In conclusion, the methodology was validated under the tested conditions.
\end{abstract}

Uniterms: Validation. Nitrite. Spectrophotometric method. Ham pate.

O objetivo deste trabalho foi validar o método espectrofotométrico para determinação de nitrito usando como matriz patê de presunto. As condições analíticas usadas foram comprimento de onda de $540 \mathrm{~nm}$ e leitura das amostras entre 40 e 70 minutos após a adição dos reagentes complexantes. As características de desempenho testadas foram linearidade, efeito de matriz, seletividade, limite de detecção do equipamento e do método, limite de quantificação, exatidão, precisão e robustez. A linearidade foi obtida na faixa de trabalho estudada $(0,125$ a $3 \mu \mathrm{g}$ de nitrito/mL) e não foi observado efeito de matriz. A concentração de ácido ascórbico na amostra não interferiu na análise e o eritorbato de sódio possuiu interferência negativa para concentrações acima de $2,5 \mathrm{mg} / 100 \mathrm{~g}$ de amostra. O limite de detecção foi definido em $12,5 \mathrm{mg}$ de nitrito/ $\mathrm{kg}$ de patê e o limite de quantificação em $25 \mathrm{mg}$ de nitrito/kg de amostra. O método apresentou repetitividade e reprodutibilidade intra-laboratorial. A exatidão foi avaliada através dos valores de recuperação que variaram entre 84 e 110\%. Na avaliação da robustez, as variações realizadas no procedimento de extração foram dependentes do nível de concentração existente na amostra. Concluiuse que a metodologia pôde ser validada nas condições testadas.

Unitermos: Validação. Nitrito. Espectrofotometria. Patê de presunto.

\section{INTRODUCTION}

The Ministry of Agriculture, Livestock and Sup-

\footnotetext{
*Correspondence: P. B. Reis. Departamento de Tecnologia e Inspeção de Produtos de Origem Animal, Escola de Veterinária, Universidade Federal de Minas Gerais, Av. Antônio Carlos, 6627, Caixa Postal n 567 - 30123-970 - Belo Horizonte - MG, Brasil. E-mail: patybreis@yahoo.com.br; patricia@ima.mg.gov.br.
}

plying (MAPA) regulates the use of nitrate and nitrite in meat products, and according articles $365,372,373$ from RIISPOA, Brazil (1952), a maximum of $200 \mathrm{mg}$ of nitrite $/ \mathrm{kg}$ of product is tolerated in meat products and, separately, a maximum of 1 part per thousand of nitrate. When sodium and potassium nitrates and nitrites are used in any combination, the amount of nitrite cannot surpass $200 \mathrm{mg} / \mathrm{kg}$. Nitrates and nitrites can be used as sodium 
nitrite $\left(\mathrm{NaNO}_{2}\right)$, potassium nitrite $\left(\mathrm{KNO}_{2}\right)$, sodium nitrate $\left(\mathrm{NaNO}_{3}\right)$, potassium nitrate $\left(\mathrm{KNO}_{3}\right)$, and its combinations. When nitrate is used, it is required the use of some reducer bacteria to transform it into nitrite, however this change is slow and difficult to control. Therefore, the direct addition of a well-known amount of nitrite makes the cure process easier and diminishes the color and taste variation in cured products (Chichester, Tanner Jr., 1972).

Nitrates and nitrites are additives largely used in meat industry, and they prevent the growth of Clostridium botulinum, provide the products with a pinkish color, cured meat typical flavor, and possess antioxidant effects (Kilic, 2000). However, these additives can cause serious damages to health; the nitrite combines with the secondary and tertiary amines present in the meat, creating nitrosamines, that are highly carcinogenic substances. They can also combine with hemoglobin creating methemoglobin, which damages the blood oxygen transport. The long term nitrite intake can causemethemoglobinemia, mainly in children, and the nitrite intoxication causes vasodilatation, smooth muscle relaxation, face redness, gastrointestinal discomfort, headache, cyanosis and vomiting. The n-nitrate compounds formed from the nitrite reactions with the amines are mutagenic and teratogenic (Harada, Silva, 2002).

Several techniques are used to detect and quantify nitrites in meat products. Between them, liquid chromatography, gas chromatography and UV/visible spectrophotometry. Between the advantages of the chromatographic methods, are not only the simultaneous detection of nitrites and nitrates, but also their fast analysis; however, it is an analytical process with high cost equipments and reagents (Schuster, Lee, 1987). The spectrophotometric analyses have been largely used for the detection and quantification of nitrate and nitrite in meat products, vegetables, legumes and water. Their advantages are the low cost method, and the fact that they meet the analyte accomplishment characteristics (Pringues et al., 1995).

The validation of an analytical method is made by the assessment of its performance criteria. The most common performance criteria are: selectiveness, which is the method capacity to identify the specific investigated compound between many others; linearity, which is the method capacity to obtain results that are directly proportional to the analyte amount that is present in the sample; precision, which is the the proximity obtained in the result, respecting to many measurements developed with the same sample; accuracy, which is the proximity of obtained results to the real analyte amount into the sample; detection limit, which is the minimum amount of analyte that is possible to detect; quantifying limit, which is the minimal amount of analyte present in the sample that can be quantified; and robustness, which is the rehearsal method capacity in resisting from certain variations in the analytical parameters (Leite, 1996; Eucharem, 1998; Brasil, 2003).

The purpose of this study was to validate spectrophotometry, as nitrite detection and quantifying method in ham pate.

\section{MATERIAL AND METHODS}

This experiment took place in the Physical/Chemical Sector of Animal Source Products of the National Agricultural Laboratory (LANAGRO), in Pedro Leopoldo - MG, according Brazil methodology (1990). A Genesys 10UV sample reader spectrophotometer was used. The analytical conditions used were as follows: $540 \mathrm{~nm}$ wavelength and optical time to read the samples after the complexating reactors addition, varying from 40 to 70 minutes.

The evaluated performance criteria were linearity, matrix effect, selectiveness, detection and quantification limits, precision, accuracy and robustness. For the performance criteria, the following concentrations of the evaluation standard-solution of sodium nitrite were used: $0.125 ; 0.250 ; 0.5 ; 1.2$; and $3 \mu \mathrm{g} / \mathrm{mL}$, and ham pate blank matrixes were added at $12.5 ; 25 ; 50 ; 100 ; 200$ and 300 concentrations of nitrite/product $\mathrm{kg}$. The concentration of $200 \mathrm{mg}$ of nitrite/product $\mathrm{kg}$, the maximum value allowed by law, corresponds to the $2 \mu \mathrm{g} / \mathrm{mL}$ standard-curve. The standard-curve was repeated in all days of analysis.

\section{RESULTS AND DISCUSSION}

\section{Linearity}

The determination coefficients $\left(\mathrm{r}^{2}\right)$ evaluated in the linearity vary from 0.9943 to 0.9976 , being all of them superior than the usually required ones, proposed by Chasin et al. (1998), who has recommended coefficients above 0.98 .

\section{Selectiveness}

\section{Ascorbic acid test}

The results about the selectiveness test using ascorbic acid as an interfering are shown at Table II.

It is observed at Table I that the concentration values obtained in the sample analyses containing nitrite and ascorbic acid, were not different from the values of samples containing only nitrite. This result shows that ascorbic acid has not interfered over nitrite spectrophotometric analyses, at any studied concentration. 
TABLE I - Material and methods used at each performance criterion tested

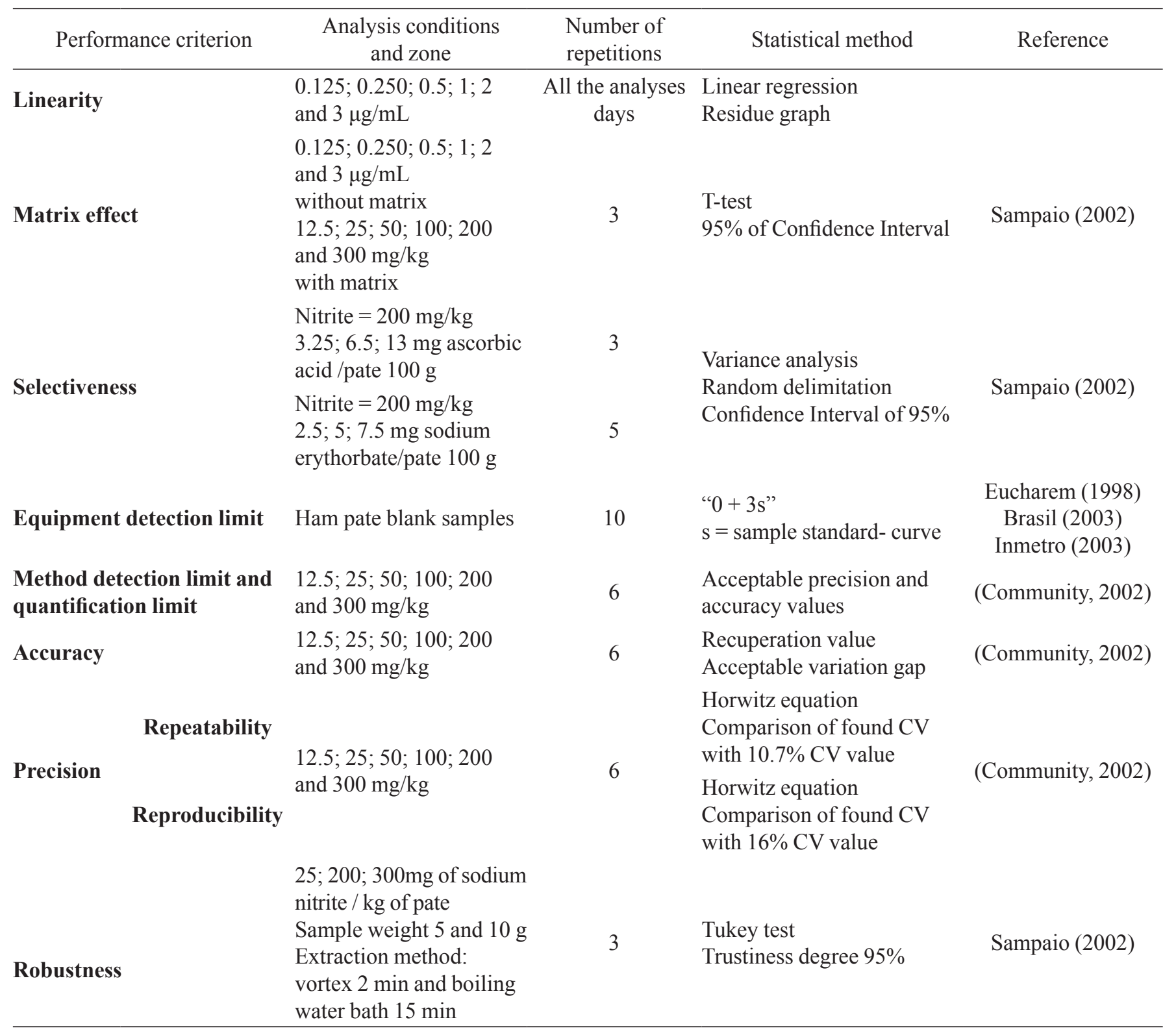

\section{Sodium erythorbate test}

The results about the selectiveness test using sodium erythorbate as an interfering are shown at Table III.

As observed, the sodium erythorbate has interfered in the nitrite spectrophotometric analyses over a sodium erythorbate concentration of $2.5 \mathrm{mg} / 100 \mathrm{~g}$ of pate. The nitrite concentration average obtained in the samples containing nitrite plus $2.5 \mathrm{mg}$ of sodium erythorbate $/ 100 \mathrm{~g}$ of pate had the same statistical value as the control group (containing only nitrite). However, the nitrite sample averages containing nitrite plus $5 \mathrm{mg}$ of sodium erythorbate $/ 100 \mathrm{~g}$ and nitrite plus $7.5 \mathrm{mg}$ of sodium erythorbate $/ 100 \mathrm{~g}$ were statistically different from the control group.
TABLE II - Ascorbic acid addition effect in nitrite quantification. All pate samples have the concentration of $200 \mathrm{mg} / \mathrm{kg}$ of ascorbic acid

\begin{tabular}{ll}
\hline Ascorbic acid addition $(\mathrm{mg} / 100 \mathrm{~g})$ & nitrite $(\mathrm{mg} / \mathrm{kg})$ \\
\hline 0 & $204.53^{\mathrm{a}} \pm 13.05$ \\
3.25 & $173.07^{\mathrm{a}} \pm 28.03$ \\
6.5 & $197.32^{\mathrm{a}} \pm 13.91$ \\
13 & $193.58^{\mathrm{a}} \pm 13.89$ \\
\hline
\end{tabular}

Non-capitalized letters in the column indicates different statistical averages by Tukey test $(\mathrm{P}<0.05)$. 
TABLE III - Sodium erythorbate addition effect in nitrite quantification. All pate samples have the concentration of $200 \mathrm{mg} / \mathrm{kg}$ of sodium erythorbate

\begin{tabular}{lc}
\hline Sodium erythorbate addition $(\mathrm{mg} / 100 \mathrm{~g})$ & nitrite $(\mathrm{mg} / \mathrm{kg})$ \\
\hline 0 & $209.32^{\mathrm{a}} \pm 1.9$ \\
2.5 & $189.08^{\mathrm{ab}} \pm 5.3$ \\
5 & $173.05^{\mathrm{b}} \pm 22.1$ \\
7.5 & $134.05^{\mathrm{c}} \pm 20.2$ \\
\hline
\end{tabular}

Non-capitalized letters in the column indicates different statistical averages by Tukey test $(\mathrm{P}<0.05)$.

\section{Matrix Effect}

The matrix effect was evaluated through the angle coefficient (a) value comparison obtained in samples with and without matrix. The angle coefficient values were $0.9136 ; 0.9525$ and 0.9535 for the standard curves with matrix standard addition, and $0.9118 ; 0.9543$ and 0.9648 for the pattern curves without matrix standard addition. The angle coefficient average values were compared by the t-test, in which the t calculated (0.0982) was inferior than the tabulated $\mathrm{t}(4.032)$ being the confidence interval of $95 \%$, so the matrix effect was not identified (Sampaio, 2002).

\section{Detection and quantification limit}

For the definition of equipment detection limit, some tests using the " $0+3 \mathrm{~s}$ " formula have been made (Inmetro, 2003). The blank matrix obtained average values of $7.225 \mathrm{mg}$ of $\mathrm{n}$ itrite $/ \mathrm{kg}$ of product and the standard deviation " $s$ " was 0.78 , therefore the value obtained by the utilization formula was $9.56 \mathrm{mg}$ of nitrite $/ \mathrm{kg}$ of pate.

For the determination method of detection limit, a recovery average of twelve nitrite samples added at the concentration of $12.5 \mathrm{mg} / \mathrm{kg}$ was observed, and the detection limit method was defined as $12.5 \mathrm{mg}$ of nitrite $/ \mathrm{kg}$ of pate. This result was based on acceptable precision and recovery values according to Community (2002), in which the acceptable recovery values vary from 80 to $110 \%$, and the acceptable variation coefficient is of $10.7 \%$ for repeatability and $16 \%$ intra-laboratory reproducibility conditions (Community, 2002). The recovery values obtained in this concentration varied from 35 to $84 \%$, but only one recovery value, in twelve samples, above $80 \%$ was found. For the precision values, in both analyzed levels, the nitrite concentration of $12.5 \mathrm{mg} / \mathrm{kg}$ of pate was the only one that obtained variation coefficient values higher than the values accepted by the Directiva 2002/657/CE (Community, 2002).

The quantification limit was of $25 \mathrm{mg}$ of nitrite/product $\mathrm{kg}$ and this was the second minor concentration used in the standard curve. Twelve blank matrix nitrite analyses added were done at this concentration, and the recovery average of these samples was of $81 \%$ and the variation coefficient was of $10.3 \%$, reaching the acceptable precision and accuracy criteria according Directiva 2002/657/ CE (Community, 2002).

\section{Precision}

\section{Repeatability}

According to Directiva 2002/657/CE from Community (2002), the acceptable variation gap for the precision in repeatability conditions is of $10.7 \%$. This value was calculated starting from the Horwitz equation (CV $\left.=2^{(1-0,5 \log \mathrm{c})}\right)$ used for intra-laboratory reproducibility. In the repeatability case the $\mathrm{CV}$ value should correspond to $2 / 3$ of the calculated value for intra-laboratory reproducibility.

The results found in the analyses repeatability are demonstrated at Table IV. The variation coefficient among six independent repetitions at the same level of nitrite concentration was within the established standards of the Directiva 2002/657/CE from Community (2002).

TABLE IV - Concentration values obtained in repeatability from six repetitions of six analyzed nitrite concentrations, and respective variation coefficient values

\begin{tabular}{lccccccc}
\hline Concentration $(\mathrm{mg} / \mathrm{kg})$ & Matrix 1 & Matrix 2 & Matrix 3 & Matrix 4 & Matrix 5 & Matrix 6 & CV (\%) \\
\hline 25 & 23.36 & 21.51 & 21.73 & $*$ & 20.99 & 22.38 & 4.2 \\
50 & 50.70 & 50.96 & 51.06 & 48.90 & 49.81 & 51.73 & 2.0 \\
100 & 105.48 & 110.42 & 107.21 & 107.17 & 110.66 & 105.35 & 2.1 \\
200 & 197.41 & 201.99 & 206.93 & 207.32 & 206.41 & 205.65 & 1.9 \\
300 & $*$ & 295.56 & 293.29 & 293.18 & 292.77 & 294.58 & 0.4 \\
\hline
\end{tabular}

* Missing numbers during the procedures. 
TABLE V - Obtained concentration values from intra-laboratory reproducibility, after six repetitions, from six analyzed nitrite concentrations and respective variation coefficient values

\begin{tabular}{lccccccc}
\hline Concentration $(\mathrm{mg} / \mathrm{kg})$ & Matrix 1 & Matrix 2 & Matrix 3 & Matrix 4 & Matrix 5 & Matrix 6 & CV (\%) \\
\hline 25 & 18.77 & 18.67 & 16.88 & 17.40 & 21.09 & 19.93 & 8.3 \\
50 & 51.42 & 51.10 & 50.36 & 49.63 & 51.84 & 51.63 & 1.7 \\
100 & 106.39 & 103.02 & 106.28 & 107.33 & 105.54 & 106.07 & 1.4 \\
200 & 210.64 & 206.85 & 202.32 & 208.01 & 207.80 & 208.22 & 1.3 \\
300 & 291.20 & 293.2 & 290.89 & 295.52 & 290.15 & 293.73 & 0.7 \\
\hline
\end{tabular}

\section{Reproducibility}

At Table $\mathrm{V}$ it is possible to observe the obtained results from the analyses done by other analyst, but using the same laboratory and equipment. The concentration levels studied $(25,50,100,200$ and $300 \mathrm{mg} / \mathrm{kg})$, in six totally independent repetitions, obtained the variation coefficient within the standards established by Directiva 2002/657/CE from the Community (2002), which is $16 \%$ as demonstrated in the Horwitz equation. In the equation $\mathrm{CV}=2^{(1-0,5 \log \mathrm{c})}$, $\mathrm{c}$ is the used mass fraction and, in this case, $\mathrm{c}=10^{-6}$, because the used mass fraction was $\mathrm{mg} / \mathrm{kg}$. Table V shows the obtained variation coefficient from the analyses done by the analyst in the intra-laboratory reproducibility.

To calculate the variation coefficient values obtained for the reproducibility, Tables IV and V were considered, representing the obtained values in the analyses made by the two participant analysts of this performance characteristic. The obtained variation coefficient values for the intralaboratory reproducibility were as following (Table VI).

TABLE VI - Standard deviation method and obtained variation coefficient values for the intra-laboratory reproducibility

\begin{tabular}{lcc}
\hline $\begin{array}{l}\text { Concentration } \\
(\mathrm{mg} / \mathrm{kg})\end{array}$ & $\begin{array}{c}\text { Pattern } \\
\text { deviation }\end{array}$ & $\begin{array}{c}\text { Variation } \\
\text { coefficient }(\%)\end{array}$ \\
\hline 25 & 2.087 & 10.3 \\
50 & 0.921 & 1.8 \\
100 & 2.116 & 2.0 \\
200 & 3.571 & 1.7 \\
300 & 1.785 & 0.6 \\
\hline
\end{tabular}

In all studied concentration, the obtained variation coefficient values for the intra-laboratory reproducibility were inferior to $16 \%$, according to the Horwitz Equation (Community, 2002).

\section{Accuracy}

At Table VII, the obtained recovery values in the accuracy test are presented.
TABLE VII - Obtained recovery values in the accuracy, respective acceptable variation gaps in the studied concentration zone, and variation coefficients

\begin{tabular}{lccc}
\hline $\begin{array}{l}\text { Concentration } \\
(\mathrm{mg} / \mathrm{kg})\end{array}$ & $\begin{array}{c}\text { Recovery } \\
\text { values (\%) }\end{array}$ & $\begin{array}{c}\text { Acceptable } \\
\text { variation } \\
\text { gaps (\%) }\end{array}$ & $\begin{array}{c}\text { CV values } \\
(\%)\end{array}$ \\
\hline 25 & 84 to 93 & 80 to 110 & 4.1 \\
50 & 97.8 to 103.5 & 80 to 110 & 2.0 \\
100 & 105.4 to 110.7 & 80 to 110 & 2.2 \\
200 & 98.7 to 103.7 & 80 to 110 & 1.9 \\
300 & 97 to 98 & 80 to 110 & 0.4 \\
\hline
\end{tabular}

In the nitrite concentrations of $25 ; 50 ; 100 ; 200$ and $300 \mathrm{mg} / \mathrm{kg}$ of pate, the found recovery values were within the acceptable variation gap. It was observed that as higher the analyzed concentrations, as higher the recovery values; and as lower the observed variation coefficient(thanks to higher amount of analyte), as lower the interference caused by losses. It is possible to observe that the recuperation values are within the acceptable gap, according to Directiva 2002/6.57/CE, in all studied concentrations (Community, 2002).

\section{Robustness}

The amount of weighed sample for the spectrophotometric nitrite analyze is dependent on the nitrite concentration present in the sample, according the analyzed results obtained (Table VIII). However, for the sample containing $25 \mathrm{mg}$ of nitrite $/ \mathrm{kg}$ of pate, it is recommended to weigh $10 \mathrm{~g}$ of pate, according to the traditional methodology (Brasil, 1999). For the samples containing 200 or $300 \mathrm{mg}$ of nitrite $/ \mathrm{kg}$ of pate, $5 \mathrm{~g}$ of sample should be weighed for the nitrite spectrophotometric analyze, which facilitates the analyte extraction process, thanks to the easier procedure of weighing $5 \mathrm{~g}$ instead of $10 \mathrm{~g}$, when a large amount of analyzes are made in a single day, considering that for 
the nitrite analysis, the analyte extraction should be made in the same day.

TABLE VIII - Nitrite concentration analyzed in robustness weighing 5 and $10 \mathrm{~g}$ of sample, and obtained results in statistical analysis

\begin{tabular}{lcc}
\hline $\begin{array}{l}\text { Concentration } \\
(\mathrm{mg} / \mathrm{kg})\end{array}$ & $5 \mathrm{~g}$ & $10 \mathrm{~g}$ \\
\hline 25 & $16.51^{\mathrm{a}}$ & $22.96^{\mathrm{a}}$ \\
200 & $213.86^{\mathrm{a}}$ & $204.90^{\mathrm{b}}$ \\
300 & $310.03^{\mathrm{a}}$ & $287.05^{\mathrm{b}}$ \\
\hline
\end{tabular}

Non-capitalized letters in the column indicate different statistical averages by Tukey test $(\mathrm{P}<0.05)$.

As it could be observed at (Table IX), the extraction method used in the analytical procedure was dependant on the nitrite concentration contained in the sample. In the sample containing $25 \mathrm{mg}$ of nitrite/ $\mathrm{kg}$ of pate, both extraction analyte methods were efficient. However, for the concentrations of 200 and $300 \mathrm{mg}$ of nitrite $/ \mathrm{kg}$ of pate, the recommended analyte extraction is of 15 minutes in a boiling water bath, because it was statistically superior, when compared to results obtained in the analyte extraction for two minutes in vortex. To create a pattern, it is recommended the analyte extraction by bath of boiling water for 15 minutes, because this method covers efficiently all studied concentrations.

TABLE IX - Nitrite concentrations analyzed for robustness, using both proposed methods, and obtaining results in statistical analyses

\begin{tabular}{lcc}
\hline $\begin{array}{l}\text { Concentration } \\
(\mathrm{mg} / \mathrm{kg})\end{array}$ & \multicolumn{2}{c}{ Extraction methods } \\
\hline 25 & Vortex & Boiling water bath \\
200 & $19.62^{\mathrm{a}}$ & $19.86^{\mathrm{a}}$ \\
300 & $211.58^{\mathrm{b}}$ & $207.18^{\mathrm{a}}$ \\
\hline
\end{tabular}

Non-capitalized letters in the column indicate different statistical averages by the Tukey test $(\mathrm{P}<0.05)$.

\section{CONCLUSION}

According to all tested conditions in this study, the spectrophotometric analytical methodology for nitrite detection and quantification in ham pate was validated.

\section{ACKNOWLEDGMENTS}

Special thanks to Agriculture, Livestock and Supplying Ministry, especially to the director and workers of LANAGRO - Pedro Leopoldo/MG, by allowing us to develop this work.

\section{REFERENCES}

BRASIL. Agência Nacional de Vigilância Sanitária. Resolução RE, $n^{\circ} 899$ de 29 de maio de 2003. Determina a publicação do guia de validação de métodos analíticos e bioanalíticos. Diário Oficial da União, Brasília, 02 de jun. 2003. Available at: <www.anvisa.gov.br>. Access on: Jan. 31th 2006.

BRASIL. Decreto Federal n 30.691 de 29 de mar. 1952 e alterações. Aprova o Regulamento de Inspeção Industrial e Sanitária de Produtos de Origem Animal. Aprovado pelo Diário Oficial da União. Brasília, 07 de jul. de 1952. Available at: $<$ www.agricultura.gov.br $>$. Access on: Aug. 23th. 2005.

BRASIL. Ministério da Agricultura, Pecuária e Abastecimento. Instrução Normativa, n 20 de 9 de set. 1999. Métodos Analíticos Oficiais Físico-Químicos para Controle de Carnes, Produtos Cárneos e seus Ingredientes, Sal e Salmoura. Diário Oficial da União. Brasília, 27 de jul. de 1999. Available in: $<$ www.agricultura.gov.br>. Access on: Aug. 31th. 2005.

CHASIN, A. A. M.; NASCIMENTO, E. S.; RIBEIRO NETO, L. M.; SIQUEIRA, M. E. P. B.; ANDRAUS, M. H.; SALVADORI, M. C.; FERNÍCOLA, N. A. G.; GORNI, R.; SALCEDO, S. Validação de métodos em análises toxicológicas: uma abordagem geral. Rev. Bras. Toxicol., v. 11, n. 1, p. 1-6, 1998.

CHICHESTER, D. F.; TANNER JR, F. W. Antimicrobial Food Additives. In: FURIA, T. E. Handbook of Food Additives. Palo Alto: CRC, 1972. v.1, p. 137-207.

EUROPEAN ECONOMIC COMMUNITY. August/12/2002. Commission decision executes the disposed in Directiva 2002/657/CE from council related to analytical methods performance and to results interpretation. Europ. Commun. Offic. J., v.657, 2002, p.L 221/8 - L 221/36.

EURACHEM. The fitness for purpose of analytical methods: A laboratory guide to method validation and related topics. Teddington: LGC, 1998. 61p.

HARADA, M. M.; SILVA, M.L. Nitrito e nitrato x segurança alimentar. Rev. Nac. Carne, São Paulo, v.26, n.308, p.105106, 2002. 
INMETRO. DOQ-CGCRE-008: Chemical essay orientations about validation methods. Revision 01. [S.I.], 2003. Available in: <http://www.inmetro.gov.br/kits/doqcgcre008r01.pdf $>$. Access on: Jan. 15th. 2006.

KILIC, B. Residual nitrite: a concern in cured meat products. Meat process., Mt. Morris, v.39, n.2, p.40-41, 2000.

LEITE, F. Validação em análise química. Campinas-SP: Átomo, 1996. 124p.

PRINGUEZ, E.; SAUDE, I.; HULEN, C. Improvement of Standard Method IDF $95^{\mathrm{A}}: 1984$ for Determination of the Nitrate Contents of Dried Milk. J. Food Compos. Anal., Blacksburg, v.8, n.1, p. 344-350, 1995.
SAMPAIO, I. B. M. Estatística aplicada à experimentação animal. 2 ed. Belo Horizonte: FEPMVZ, 2002. 265p.

SCHUSTER, B. E.; LEE, K. Nitrate and Nitrite Methods Analysis and Levels in Raw Carrots, Processed Carrots and in Selected Vegetables and Grain Products. J. Food Sci., Chicago, v. 52, n.6, p. 1632-1636, 1987.

Recebido para publicação em 18 de abril de 2007. Aceito para publicação em 17 de novembro de 2008. 